\title{
obituaries
}

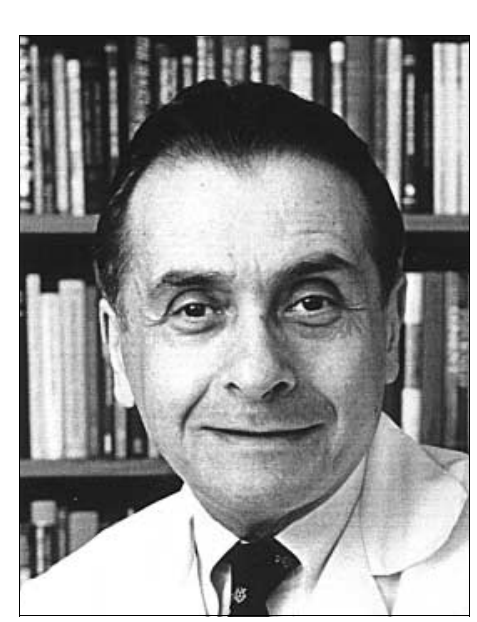

Dr Samuel B. Guze

Formerly Consultant Professor of Psychiatry, School of Medicine, Washington University in St Louis, USA

Dr Samuel B. Guze died on 19 July 2000 at Barnes-Jewish hospital of complications from a bone marrow disorder. He was 76 years old.

Dr Guze was among the first to use studies of twins as a means of identifying the role of heredity in psychiatric illness. His work spawned great interest in the genetics of psychiatric disorders.

"Dr Guze has been one of the people most responsible for the fact that in the second half of the 20th century, psychiatry has moved into the mainstream of medical science," said Dr Richard W. Hudgens, Professor of Psychiatry at the School of Medicine: "He has been the most articulate and consistent advocate of clinical psychiatry as a scientific endeavour."

Dr Guze served as Vice Chancellor and President of the Washington University Medical Center from 1971-1989 - a period of its rapid expansion in medical care and medical research. He was head of the department of psychiatry 1975-1989 and again 1993-1997.

Dr Guze was also Psychiatrist-in-Chief at Barnes-Jewish and St Louis Children's Hospitals. He trained hundreds of psychiatrists. In 1980 Guze and his colleagues helped to create the American Psychiatric Association Diagnostic and Statistical Manual of Mental Disorders, a manual that has become the standard reference text for diagnosing mental illness. He published more than 200 scientific papers and several books. He was also the recipient of many awards for his contributions to the advancement of psychiatry, including his most recent in January - the Dr Thomas William Salmon Medal from New York Academy of Medicine.
Born in New York, Dr Guze graduated from a high school in New York at the age of 15 and attended the City College of New York. He earned his medical degree from Washington University. He started his career as an internist, but switched to psychiatry.

In 1998 Guze and his wife of 54 years, Joy, established the Samuel B. Guze Professorship in Psychiatry at Washington University.

He was the Spencer T. Olin Professor of Psychiatry at Washington University at the time of his death. He is survived by his wife, son, daughter and five grandchildren.

\section{Paul Harris}

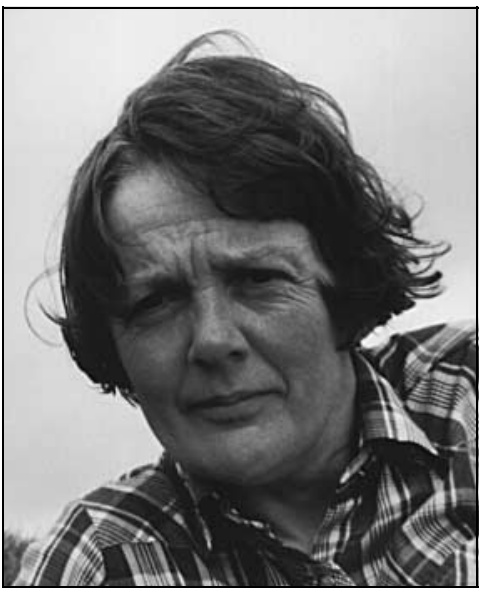

\section{Rowan Adams}

Formerly Consultant Psychiatrist at the Duncan Clinic, Edinburgh 1944-2000

Rowan Adams was killed on 3 May 2000 in a climbing accident on the Jungfrau glacier in Switzerland. The accident happened while she was practising safety manoeuvres prior to an expedition to cross from Grindelwald to Grimsel Pass with a small party of Scottish and Canadian skiers, headed by an experienced Canadian guide.

Rowan was born on 30 October 1944 in Carlisle but spent most of her early life in Canada, moving to Scotland in 1971. She came from a distinguished medical family that included an uncle, Donal Sheehan - Professor of Anatomy at New York University College of Medicine and another uncle, Harold Sheehan (of Sheehan's syndrome) - Professor of Pathology at Liverpool. She attended the Central Collegiate Institute in Calgary, Alberta, where she was awarded the Viscount Bennett Scholarship as best all-round student in Alberta. She then went to McGill University in
Montreal as a McGill scholar, where she was particularly proud to be 'top gentile' in her final medical exams. She received a BSC in psychology and genetics, and MD.CM at McGill. She then trained at Ottawa Civic Hospital and in dermatology at Vancouver General Hospital. In Scotland she worked as a dermatologist at Dundee Royal Infirmary, Edinburgh Royal Infirmary, Foresterhill, Aberdeen, Stobhill General Hospital, Glasgow Royal Infirmary and Belvedere Hospital, Glasgow. She was elected MRCP in 1981 and in 1986 MRCPsych. She was appointed a consultant psychiatrist in Monklands Hospital before becoming a consultant psychiatrist at the Royal Edinburgh Hospital in 1995.

Rowan was a committed doctor who always thought of her patients' interests first. She was dedicated to her work, and passionate and strong-minded about services. She was very kind, and her combination of care and attention to detail encouraged many trainee psychiatrists and medical students in the Royal Edinburgh scheme. She was heavily involved in the enhancement of the home and community care team, which had started the year before her appointment, and in developing a primary care liaison team with general practitioners in the South-East of Edinburgh. In this work, again her commitment to high quality care and a patient orientated service shone through. She was an examiner and college tutor for the Royal College of Psychiatrists and a national panellist for the appointment of consultant psychiatrists.

Rowan was always busy outside psychiatry. She took a great interest in cultural affairs, often being seen at the Traverse Theatre, the Queen's Hall and the Edinburgh Festival Theatre. Her love of sports was also well known. She was an expert downhill and cross-country skier. She enjoyed cycling and swimming and made many canoe trips in Ontario, Quebec and British Columbia. She climbed and skied extensively in the Rockies, Selkirks, Alps, New England, Scotland, Norway, Spain and Greece. She was well read, with a detailed knowledge of Victorian women writers.

Rowan was a first class doctor, mother and wife, and will be greatly missed. She is survived by her parents Margaret Hopwood and John Hopwood, QC of Calgary; her husband Gordon Adams, an economist, whom she met at McGill and married in May 1967; and by her two children Ewan (26), an educational researcher at Bristol University, and Jean (22), a medical student at the University of Newcastle.

Gordon Adams and Ken Slatford 